\title{
PELAKSANAAN ASSESMEN TENTANG REHABILITASI TERHADAP KORBAN PENYALAHGUNAAN NARKOTIKA DITINJAU DARI PERATURAN PERUNDANG-UNDANGAN
}

\section{IMPLEMENTATION OF ASSESSMENT ABOUT REHABILITATION TOWARD NARCOTICS ABUSE VICTIMS VIEWED FROM LEGISLATION}

\author{
Muslikan dan \\ Muhammad Taufiq
}

\author{
Program Studi Ilmu Hukum Sekolah Pascasarjana \\ Universitas Djuanda Bogor \\ Jl. Tol Ciawi No. 1, Kotak Pos 35, Bogor 16720. \\ Korespondensi: Muslikan, Tel. - \\ e-mail : muslikana6@gmail.com
}

\begin{abstract}
Jurnal
Living Law,

Vol. 11, No.

1 ,

2019

hlm. 61-80

Abstract : The purpose of this study are: 1) To find out and analyze the process of applying rehabilitation to victims of narcotics abuse, 2) To find out and analyze the implementation of assessments of rehabilitation of victims of narcotics abuse in terms of legislation. The research method used is normative juridical research that takes a qualitative approach. The results are: 1) The process of implementing rehabilitation for addicts and victims of narcotics abuse by the Bogor Regency Narcotics Rehabilitation Center is in accordance with the laws and regulations. However, it does not rule out the shortcomings that always exist in carrying out these rules, 2) The implementation of assessments of narcotics abuse victims in the Indonesian National Police is the same as those carried out by the National Narcotics Agency, namely if victims of narcotics report without arrest, the police will direct / recommend directly to the Obligatory Recipient Institution Report (IPWL) and if the victims of narcotics abusers are caught by the Police then the process, receipt of assessment requests from investigators in 24 (twenty-four) hours, and the integrated assessment team provides recommendations on the results of the period of assessment no later than 6 (six) days to the investigator to be reported in writing to the local district court.
\end{abstract}

Keywords : Narcotics, assessment of rehabilitation, Constitution

\begin{abstract}
Abstrak : Tujuan penelitian ini yaitu untuk mengetahui dan menganalisis: 1) proses penerapan rehabilitasi terhadap korban penyalahgunaan narkotika, 2) pelaksanaan assesmen tentang rehabilitasi terhadap korban penyalahgunaan narkotika ditinjau dari peraturan perundang-undangan. Metode penelitian yang digunakan adalah penelitian yuridis normatif yang melakukan pendekatan kualitatif. Hasil dari penelitian ini yaitu: 1) Proses penerapan rehabilitasi bagi korban penyalahgunaan narkotika oleh Balai Rehabilitasi Narkotika Kabupaten Bogor sudah sesuai dengan peraturan perundang-undangan. Namun, tidak menutup kemungkinan kekurangan itu selalu ada dalam menjalankan aturan tersebut, 2) Pelaksanaan assesmen terhadap korban penyalahgunaan narkotika pada Kepolisian Republik Indonesia sama dengan yang dilaksanakan oleh Badan Narkotika Nasional, yaitu jika korban narkotika melakukan pelaporan tanpa proses penangkapan, maka pihak Kepolisian akan mengarahkan langsung ke Institusi Penerima Wajib Lapor (IPWL). Dan jika korban penyalahguna narkotika tertangkap oleh pihak Kepolisian, maka prosesnya, penerimaan permohonan assesmen dari penyidik paling lama $1 \times 24$ jam, dan tim assesmen terpadu memberikan rekomendasi hasil assesmen dengan jangka waktu paling lama 6 (enam) hari kepada penyidik untuk dilaporkan tertulis kepada pengadilan negeri setempat.
\end{abstract}

Kata Kunci : Narkotika, Assesmen rehabilitasi, Undang-undang. 


\section{PENDAHULUAN}

Setiap negara bertujuan mensejahterakan rakyat dan memajukan negaranya, menentang segala bentuk perbudakan dan penjajahan, sehingga kemandirian dan kemerdekaan dapat terwujud tanpa ada campur tangan dari pihak asing. Setelah mengalami penjajahan yang teramat panjang kurang lebih 3,5 Abad oleh Kolonial Belanda dan 3,5 tahun oleh Jepang yang membuat bangsa Indonesia sangat menderita ${ }^{1}$, Negara Republik Indonesia 73 tahun silam telah menyatakan kemerdekaan dan menentang segala bentuk penjajahan di atas dunia seperti tertuang dalam Pembukaan Undang-undang Dasar Tahun 1945 Alenia I, "Bahwa sesungguhnya kemerdekaan itu ialah hak segala bangsa dan oleh sebab itu, maka penjajahan di atas dunia harus dihapuskan, karena tidak sesuai dengan perikemanusiaan dan perikeadilan."

Namun sampai abad ke-21 penjajahan di dunia belum berakhir di mana penjajahan berbeda zaman berbeda cara dan tujuan, tempo dulu penjajahan dengan konfrontasi kekuatan militer/perang, dewasa ini menggunakan penjajahan ekomomi, intelegensi, kebudayaan, cyber, obat-obatan dan lain sebagainya.

Bentuk penjajahan di Indonesia sudah sampai dalam berbagai sendi-sendi kehidupan dewasa ini, dari yudikatif, eksekutif, dan legislatif, dengan ditandainya berbagai produk hukum maupun kebijakan yang dihasilkan, cenderung bahkan memihak kepada kepentingan elit politik maupun pihakpihak tertentu bahkan kepentingan asing, di mana jauh dari rasa keadilan serta kesejahteraan masyarakat.

Negara Indonesia adalah negara yang menjunjung tinggi tegaknya hukum serta menganggap hukum sebagai panglima tertinggi, sehingga hak-hak warga negara

1"Sejarah Indonesia Singkat Penderitaan", http://sejarahrakyat.blogspot.co.id/2015/09/sejar ah-indonesia-singkat-penderitaan.html, Diakses tanggal 5 Juni 2018. dapat terjamin, sesuai dengan Pasal 28 D ayat (1) Undang-undang Dasar Negara Republik Indonesia Tahun 1945.

Dalam perjalanan perlindungan dan jaminan terhadap warga negara, terkadang masih jauh dari yang diharapkan, sebagai contoh dalam penerapan asas "equality befor the law"2 dalam kehidupan berbudaya hukum, tak sedikit masalah yang timbul, masalah besar dapat dikecilkan dan sebaliknya masalah yang kecil dapat dibesarkan, di mana hukum tumpul ke atas dan tajam ke bawah, semakin tinggi strata seseorang maka semakin kecil terkenai hukuman dan sebaliknya semakin rendah strata seseorang maka semakin besar jenis hukuman, suatu potret di mana hukum sangat sulit mancapai kata adil walaupun tujuan hukum sendiri untuk mencapai sesuatu yang seadil-adilnya.

Terhadap orang kecil (The Poor) hukum bersifat represif, sedangkan terhadap orang besar (The Have) hukum bersifat protektif dan memihaknya ${ }^{3}$. Sehingga penegakan hukum hanya sebagai retorika atau angan-angan dan sulit untuk diwujudkan, dalam proses peradilan sering dirasa keadilan jauh dari rasa nurani masyarakat baik dalam proses penyidikan, penuntutan maupun pada proses vonis di pengadilan yang merupakan gerbang terakir pintu keadilan, di mana peluang dan kesempatan lobi-lobi sering terjadi mulai dari permainan pasal yang disangkakan, besar kecilnya tuntutan serta vonis yang bisa dipesan.

Di samping aparat penegak hukum yang kurang maksimal dalam berproses dipengaruhi juga tingkat kejahatan yang semakin komplek dan canggih sampai melibatkan unsur-unsur lapisan masyarakat sampai pemangku kewenangan yang diamanatkan oleh undang-undang. Kejahatan sendiri adalah perbuatan yang melanggar undang-undang atau norma dan

${ }^{2}$ Salim, HS., Erlis Septiana Nurbani, Penerapan Teori Hukum pada Penelitian Tesis dan Disertasi, Jakarta: Raja Grafindo Persada, 2013, Hlm. 301.

3Suteki, Masa Depan Hukum Progesif, Yogyakarta: Thafa Media, 2015, Hlm. 7. 
tidak diterima di masyarakat yang menyebabkan kerugian baik secara materil maupun moril terhadap setiap orang dan negara.

W.A. Bonger dalam bukunya "pengantar tentang kriminologi" kejahatan dirasakannya sebagai perbuatan yang immoral dan a social, yang tidak dikehendaki oleh kelompok pergaulan yang bersangkutan, dan secara sadar ditentang oleh pemerintah. Dalam rumusan Paul Moedikdo Moeliono, kejahatan adalah perbuatan manusia yang merupakan pelanggaran norma yang dirasakan merugikan, menjengkelkan sehingga tidak boleh dibiarkan. ${ }^{4}$

Beberapa jenis kejahatan dapat disebutkan di sini, misalnya: ${ }^{5}$

a. Apa yang disebut kejahatan sebagai usaha (business); ialah organized crime, white collar crime, korupsi, penyelundupan;

b. Penyalahgunaan alkohol dan narkotika;

c. Tindakan terorisme;

d. Kejahatan atau pelanggaran lalu lintas.

Yang tidak pernah dipermasalahkan dalam konggres PBB sebelumnya juga mendapat perhatian, ialah kejahatan yang dilakukan oleh wanita.

Narkotika bukanlah sesuatu yang asing, di mana dapat didengar dan dibaca di media elektronik maupun media cetak. Di Indonesia, peredaran obat terlarang atau narkotika menjadi salah satu permasalahan utama yang harus segera diatasi. Meluasnya narkoba di Indonesia terutama di kalangan generasi muda karena didukung oleh faktor budaya global. Di mana budaya global dikuasai oleh budaya barat yang mengembangkan pengaruhnya melalui televisi, film-film, internet, maupun sosial media yang lainnya, di mana narkoba lebih besar dampak negatifnya dibanding manfaatnya.

${ }^{4}$ Ninik Widiyanti dan Yulius Waskita, Kejahatan dalam Masyarakat dan Pencegahannya, Jakarta: Bina Aksara, 1987, Hlm. 29.

5Ibid., HIm. 19.
Penyalahgunaan narkotika tidak saja menjadi masalah nasional, melainkan juga masalah internasional, oleh karena itu komitmen bangsa Indonesia untuk memusnahkan peredaran narkotika yang semakin tinggi. Hal ini terlihat dari pengaturan yang sudah jelas mengatur tentang penggunaan narkotika, termasuk ancaman sanksi minimum dan maksimum bagi pelaku. Namun pengaturan yang ada kaitanya dengan masalah pencucian uang (money loundering) sebagai hasil penjualan dan perdagangan narkotika dan psikotropika belum diatur seperti yang terdapat pada beberapa negara lain, padahal dampak yang ditimbulkan besar sekali. ${ }^{6}$

Para penegak hukum selama ini hanya dapat melakukan tindakan di hulu (to cut the linkage) yaitu secara preventif dan represif. sedangkan pencucian uang dapat dikatakan mempunyai modus tersendiri, pengusutannya lebih sulit, karena harus dilaksanakan secara integrated dan comperehensive dengan melibatkan instansi terkait, organisasi-organisasi internasional (NCB-Interpol) melalui kerja sama, baik bersifat bilateral, regional maupun multilateral, di samping itu memerlukan dana besar. ${ }^{7}$

Kejahatan narkotika kini sudah memperihatinkan, di mana sebelumnya narkotika hanya mencakup kalangan tertentu dan hanya terdapat di kota-kota besar, dewasa ini kejahatan narkotika menyasar ke anak-anak bahkan sampai ke pelosok-pelosok pedesaaan, tentunya dengan harga yang terjangkau dari berbagai jenis, bentuk dan ukuran. Sehingga Presiden Joko Widodo menyatakan bahwa Negara Indonesia darurat narkoba dan negara berperang melawan narkoba ${ }^{8}$.

${ }^{6}$ Hasil wawancara dengan Bapak Dr. Muhammad Taufiq, S.H., M.H., selaku Dosen Sekolah Pascasarjana Program Magister Ilmu Hukum Unniversitas Djuanda, pada tanggal 24 Maret 2018.

${ }^{7}$ Ibid.

8"Lakka Zombie dan Indonesia Darurat Narkoba”, https://news.detik.com/berita/d- 
Tempo dulu transaksi narkotika masih konvensional dengan sistem ketemu langsung, ada uang ada barang "No Money no Goods" dan jaringan peredarannya juga masih bisa dihitung dengan jari, akan tetapi dewasa ini transaksi narkotika sudah mengikuti perkembangan zaman, modusnya sudah mulai beragam dengan istilah atau sandi-sandi, bahkan narkotika bisa dipesan melalui internet/online, sebagai contoh baru-baru ini dengan peredaran jenis baru ganja sintetis merek Gorila atau Hanoman sebutan bagi kalangan penyalahguna narkotika tersebut, di mana kandungan narkotika jenis baru tersebut belum masuk dalam Undangundang Nomor 35 Tahun 2009 tentang Narkotika. ${ }^{9}$

Keadaan ini mendesak pemangku kekuasaan membuat regulasi agar perbuatan tersebut dapat dijerat dengan peraturan yang baru, dengan keluarnya Peraturan Menteri Kesehatan Republik Indonesia Nomor 02 Tahun 2017 tentang Perubahan Penggolongan Narkotika, maka penyalahguna narkotika jenis ganja sitetis/tembakau gorilla atau hanoman tersebut dapat dijerat dengan hukum yang berlaku di Indonesia.

Tak ada gading yang tak retak mungkin cocok untuk peribahasa dalam setiap produk hukum, di mana terdapat celahcelah yang memungkinkan untuk menghindari hukuman yang disanksikan. Seperti dalam Pasal 103 Undang-undang Nomor 35 Tahun 2009 tentang Narkotika sehingga dikeluarkan Surat Edaran Mahkamah Agung (SEMA) Nomor 04 Tahun 2010 tentang Penempatan Penyalahgunaan, Korban Penyalahgunaan dan Pecandu Narkotika ke dalam Lembaga Rehabilitasi Medis dan Rehabilitasi Sosial, revisi dari SEMA Nomor 07 Tahun 2009 tentang Menempatkan Pemakai Narkoba ke dalam Panti Terapi dan Rehabilitasi.

Penanganan masalah narkotika masih belum sepenuhnya maksimal, dengan

3569388/flakka-zombie-dan-indonesia-daruratnarkoba, Diakses tanggal 30 Juni 2018.

${ }^{9}$ Ibid. berbagai celah-celah hukum yang dapat menghambat dalam memberantas dan memerangi peredaran gelap narkotika, baik dalam subtansi, struktur dan budaya hukum itu sendiri, terkadang dalam penanganan perkara narkoba sendiri antara penegak hukum berbeda pendapat dengan berbagai argument, walaupun sudah diatur dalam Undang-undang Nomor 35 Tahun 2009 tentang Narkotika sudah jelas dalam pasal-pasalnya, sebagai contoh A telah tertangkap tangan telah kedapatan membawa, menyimpan, memiliki dan menguasai narkotika Golongan I jenis shabu-shabu (Amphetamin) akan tetapi berat dari Shabu-shabu tersebut di bawah ketentuan yang terdapat dalam SEMA Nomor 04 Tahun 2010, ketika dalam proses penyidikan, penyidik yakin bahwa untuk menjerat dan memberi efek jera diterapkan Pasal 114 dan atau Pasal 112 Undang-undang Nomor 35 Tahun 2009 tentang Narkotika berdasarkan keterangan saksi dan hasil penyelidikan (pengamatan, pembuntutan, wawancara, undercover buy dll.), akan tetapi jaksa selaku penuntut umum tidak sependapat dengan penyidik dengan memberi petunjuk untuk menerapkan Pasal 127 atau sebagai penyalahguna, ketika pasal tersebut dimasukan berarti ada tindakan tambahan yang harus dilakukan yaitu Assesment Rehabilitasi di mana proses hukum yang seharusnya sederhana, cepat dan murah sesuai konsep hukum modern yang tertuang dalam Undang-undang Nomor 48 Tahun 2009 tentang Kekuasaan Kehakiman jadi memakan waktu dan menambah biaya, dan bisa dibayangkan apabila seorang bandar narkotika cerdik dengan mengetahui adanya SEMA Nomor 04 Tahun 2010, tidak menutup kemungkinan mereka akan menjual atau mengedarkan narkotika dengan berat di bawah SEMA tersebut dan akan terdapat celah untuk menghindari pasal sebagai pengedar.

Narkotika merupakan sebuah ancaman besar bagi keberlangsungan hidup sebuah 
bangsa. ${ }^{10}$ Ketika narkotika sudah mulai perlahan demi perlahan beredar secara ilegal di masyarakat maka akan menimbulkan kerusakan yang di dalamnya. Kerusakan yang ditimbulkan oleh narkotika tidak hanya sebatas terjadi pada diri pengguna narkotika (merusak/menghancurkan kesehatan baik jasmani maupun emosi dan emosional) tetapi juga merusak tatanan kehidupan masyarakat, misalnya dari sisi ekonomi: penyalahgunaan narkotika juga meningkatkan biaya kesehatan baik yang dikeluarkan oleh pihak keluarga, masyarakat dan negara, sisi sosial dan pendidikan: para pencandu narkotika biasanya menjadi antisosial dan menimbulkan gangguan keamanan dan ketertiban pada lingkungannya dan merugikan masyarakat, sisi kultural: jika narkotika sudah menjadi darah dan daging dalam kehidupan masyarakat maka tidak menutup kemungkinan masyarakat akan menerima bahwa pimpinannya, polisi, hakim, jaksa advokat dan lain sebagainya pecandu narkotika sehingga apabila keadaaan demikian terjadi maka akan sangat berbahaya bagi keberlangsungan hidup bangsa dan negara, sisi keamanan nasional: karena perdagangan narkotika memiliki banyak keuntungan tidak menutup kemungkinan para pemberontak/kelompok separatis terlibat dalam peredarannya dan hasilnya digunakan untuk membiayai kegiatan pemberontakan, dan sisi penegakan hukum: penggunan narkotika yang terus menerus akan menyebabkan kecanduan yang sangat besar sehingga jika keuangan pribadi sudah tidak mampu membiayai maka tidak menutup kemungkinan untuk pemenuhannya melakukan tindak pidana lain, seperti mencuri, menjadi pengedar narkotika dan lain sebagainya. ${ }^{11}$

10 Badan Narkotika Nasional, Pencegahan Penyalahgunaan Narkoba Bagi Remaja, Jakarta: Badan Narkotika Nasional, 2011, Hlm. 1.

11 Edy Karsono, Mengenal Kecanduan Narkoba \& Minuman Keras, Bandung: CV. Yrama Widya, 2004, HIm. 22-32.
Keadaan yang ditimbulkan oleh narkotika di atas terus ditangani oleh pemerintah dengan berbagai cara baik dengan melakukan sosialisasi bahaya narkotika dan memunculkan produk hukum yang dapat memberi ruang gerak bagi penegak hukum dalam memberantas narkotika. Produk hukum utama yang dimiliki Indonesia dalam memerangi penyalahgunaan narkotika maupun peredarannya. Kejahatan narkotika sudah tidak lagi dilakukan oleh perseorangan, tetapi sudah melibatkan lebih dari satu sindikat yang terorganisasi dengan jaringan yang luas yang bekerja secara rapi dan sangat rahasia baik di tingkat nasional maupun tingkat internasional sekalipun. Berdasarkan hal tersebut guna peningkatan upaya pencegahan dan pemberantasan Narkotika telah dilakukan pembaruan terhadap Undang-undang Narkotika lama dengan Undang-undang Nomor 35 Tahun 2009 tentang Narkotika. Hal ini dapat mencegah adanya kecenderungan yang semakin meningkat baik secara kuantitatif maupun kualitatif dengan korban yang meluas, terutama di kalangan anak-anak, remaja, dan generasi muda pada umumnya. Dengan demikian, agar dapat melindungi masyarakat dari bahaya penyalahgunaan narkotika dan mencegah serta memberantas peredaran gelap narkotika, dalam undang-undang pun diatur mengenai prekursor narkotika karena prekursor narkotika yaitu zat atau bahan pemula atau bahan kimia yang dapat digunakan dalam pembuatan narkotika.

Masing-masing lembaga tersebut terus melakukan pembenahan dalam melakukan pemberantasan narkotika. BNN untuk memperkuat pemberantasan narkotika menjalin kerjasama dengan instansi lain seperti Tentara Nasional Indonesia yang tertuang didalam Memorandum of Understanding (MoU) Nomor: NK 29/V/2015/BNN Nomor : Kerma 14/V/2015 tanggal 13 Mei 2015 tentang Bantuan TNI kepada BNN dalam rangka Pencegahan dan Pemberantasan Penyalahgunaan dan Peredaran Gelap 
Narkotika dan Prekursor Narkotika serta Pelaksanaan Rehabilitasi Penyalahguna dan Pecandu Narkotika dan Prekursor Narkotika yang berisi beberapa poin penting, yaitu: ${ }^{12}$

1. Pembinaan dan pemberdayaan masyarakat anti penyalahgunaan dan peredaran narkotika dan prekursor,

2. Diseminasi informasi, advokasi tentang pencegahan penyalahgunaan dan peredaran narkotika dan prekursor,

3. Pelaksanaan pemeriksaan tes atau uji narkotika atas persetujuan para pihak yang terlibat,

4. Pelayanan rehabilitas atas pesetujuan pihak yang terlibat,

5. Penyelenggaraan kegiatan terkait pemberantasan penyalahgunaan dan peredaran narkoba yang melibatkan pihak kedua atas permintaan pihak pertama,

6. Penugasan personel terkait pemberantasan penyalahgunaan dan peredaran gelap narkoba yang melibatkan pihak kedua atas permintaan pihak pertama,

7. Pelaksanaan sosialisasi wajib lapor pecandu saat proses rehabilitasi dan terhadap penyalahgunaan prekursor,

8. Pertukaran data informasi terkait peredaran dan penyalahgunaan narkotika dengan memperhatikan kerahasiaan dan kepentingan negara.

Selanjutnya, Kepolisian Negara Indonesia juga bersinergi dengan Badan Narkotika Nasional (BNN) ditambah dengan beberapa instansi pemerintah lain dimana bergerak cepat dalam rangka penanganan pencandu narkotika, yang dilakukan oleh lembaga-lembaga terikat dengan peraturan bersama yang dibuat. Artinya, untuk melaksanakan peraturan bersama tersebut maka instansi mengeluarkan peraturan pelaksana. Kepolisian Republik Indonesia mengeluarkan surat telegram Kapolri No.: STR/865/X/2015 dan lain sebagainya.
Keterlibatan kepolisian dalam tim assesmen merupakan suatu bagian yang penting dalam penanganan pencandu narkotika karena Narkotika termasuk bagian penyidik selain BNN. Walaupun di dalam Undang-undang Nomor 35 Tahun 2009 tentang Narkotika porsi kewenangan BNN untuk kejahatan narkotika lebih besar dibandingkan dengan kepolisian. ${ }^{13}$ Namun, perlu dipahami bahwa keberadaan polisi dalam setiap penyelidikan maupun penyidikan sangat berperan besar karena pada dasarnya berfungsinya hukum di lapangan sangat ditentukan oleh kepolisian dalam merekayasa sosial.

Berdasarkan uraian latar belakang masalah tersebut di atas, maka penulis dalam penelitian ini mengambil judul tentang: "PELAKSANAAN ASSESMEN TENTANG REHABILITASI TERHADAP KORBAN PENYALAHGUNAAN NARKOTIKA DITINJAU DARI PERATURAN PERUNDANGUNDANGAN".

Dari latar belakang masalah yang telah diuraikan di atas, penulis mengidentifikasi masalah sebagai berikut:

1. Bagaimana proses penerapan rehabilitasi terhadap korban penyalahgunaan narkotika?

2. Bagaimana pelaksanaan assesmen tentang rehabilitasi terhadap korban penyalahgunaan narkotika ditinjau dari peraturan perundang-undangan?

\section{METODE PENELITIAN}

Metode penelitian yang digunakan dalam penelitian ini adalah pendekatan yuridis normatif, yaitu hukum dikonsepsikan sebagai norma, kaidah, asas atau dogma-dogma/yurisprudensi.

\section{PEMBAHASAN}

\section{A. PROSES PENERAPAN REHABILITASI TERHADAP KORBAN PENYALAHGUNAAN NARKOTIKA}

Permasalahan narkotika merupakan permasalahan yang sangat susah untuk 
dihilangkan. Selain itu permasalahan narkotika juga merupakan kejahatan luar biasa atau Extra Ordinary Crimes. Dalam perkembangannya kasus-kasus narkotika dari tahun ke tahun semakin meningkat di negara ini. Bahkan permasalahan narkotika saat ini tidak lagi secara sembunyisembunyi, tetapi sudah terang-terangan dilakukan oleh pemakai maupun pengedar dalam menjalankan aksinya.

Sebelum kita terlalu jauh berbicara tentang rehabilitasi terlebih dahulu kita perlu tahu apakah narkotika itu. Narkotika ialah zat atau obat yang berasal dari tanaman atau bukan tanaman baik sintetis maupun semi sintetis, yang dapat menyebabkan penurunan atau perubahan kesadaran, hilangnya rasa, mengurang sampai menghilangkan nyeri, dan dapat menimbulkan ketergantungan, yang dibedakan kedalam golongan-golongan sebagaimana terlampir dalam Pasal 1 angka 1 Undang-undang Nomor 35 Tahun 2009 tentang Narkotika.

Permasalahan narkotika merupakan permasalahan yang sangat kompleks dan sangat sulit untuk ditanggulangi. Walaupun sudah banyak upaya yang telah dilakukan mulai dari upaya preventif hingga upaya represif, namun permasalahan narkotika ini tidak juga hilang dari negara kita khususnya Kabupaten Bogor itu sendiri. Walaupun pengawasan yang dilakukan oleh pemerintah dan aparat setiap tahunnya semakin meningkat tapi masih belum menyurutkan niat dari pengedar untuk mengedarkan barang haram ini. Hal tersebut terjadi karena banyaknya orang yang membutuhkan dan keuntungan yang dapat didapatkan oleh pengedar dari penjualan narkotika itu sendiri. Dilihat dari keadaannya, narkotika berkembang seiring dengan perkembangan zaman, hal ini ditunjukkan dengan banyaknya orang yang menggunakan narkotika mulai dari kalangan orang dewasa hingga anak-anak, berawal dari niat coba-coba hingga untuk mendapatkan ketenangan batin dari masalah yang dihadapi, sesuai data yang ada.

\section{TABEL 1 \\ PERKEMBANGAN KASUS YANG DITANGANI DI KABUPATEN BOGOR}

\begin{tabular}{|c|c|c|c|c|}
\hline NO. & KESATUAN & $\mathbf{2 0 1 5}$ & $\mathbf{2 0 1 6}$ & $\mathbf{2 0 1 7}$ \\
\hline 1. & Polres Bogor & 184 & 204 & 249 \\
\hline
\end{tabular}

Sumber : Polres Bogor Tahun 2017.

Data di atas narkoba masih merajalela di Kabupaten Bogor dan setiap tahun menunjukkan frekuensi peningkatan yang cukup signifikan dan peran lembaga penegak hukum yang tidak tinggal diam dalam menanggulangi peredaran gelap kasus narkotika yang tidak bisa lagi dianggap mudah memberantasnya.

Efektifitas hukum menurut Scholars, diakui bahwa pada umumnya, dapat dikelompokkan dalam teori tentang perilaku hukum ialah aktualisasi kegiatan hukum. Hal tersebut berarti bahwa efektifitas hukum dapat dilihat dari aktualisasi yang dilakukan. Apakah sebuah kebijakan ataupun aturan tersebut dapat dijalankan sesuai dengan tujuan yang diinginkan. ${ }^{14}$

Rehabilitasi narkotika sendiri terdiri dari 2 (dua) jenis, yaitu: rehabilitasi medis dan rehabilitasi sosial. Pengertian rehabilitasi medis sendiri dijelaskan pada Pasal 1 angka 16 Undang-undang Nomor 35 Tahun 2009 tentang Narkotika yang menyatakan bahwa:

"Rehabilitasi medis adalah suatu proses kegiatan pengobatan secara terpadu untuk membebaskan pecandu dari ketergantungan narkotika"

Sedangkan rehabilitasi sosial juga diatur di undang-undang yang sama pada Pasal 1angka 17 yang menyatakan bahwa:

"Rehabilitasi sosial adalah suatu proses kegiatan pemulihan secara terpadu, baik fisik, mental maupun sosial, agar bekas pecandu narkotika dapat kembali melaksanakan fungsi sosial dalam kehidupan masyarakat"

14 Salim, HS., Erlis Septiana Nurbani, Op.Cit., HIm. 301. 
Dalam perkembangannya tujuan hukuman bukan hanya untuk efek jera dan pembalasan saja melainkan harus pula bermanfaat bagi korban maupun pelaku. Maka dari itu rehabilitasi bagi pecandu dan korban penyalahgunaan narkotika ini hadir untuk memberikan kesempatan kepada mereka untuk sembuh dan dapat kembali kemasyarakat seperti sebelum menggunakan narkotika.

Dalam balai rehabilitasi seorang pecandu maupun korban penyalahgunaan narkotika yang biasa disebut sebagai residen harus menjalani beberapa tahapan sampai mereka benar-benar sembuh dan kembali kemasyarakat. Adapun tahapan yang harus dijalani adalah sebagai berikut:

\section{Intake Process}

Pada tahapan ini residen akan diperiksa terlebih dahulu, baik pemeriksaan psikis, pemeriksaan fisik maupun pemeriksaan penunjang. Selain itu residen juga akan melakukan wawancara awal dan pada akhirnya dikeluarkanlah rujukan untuk residen dalam menjalani proses rehabilitasi. Pada proses ini hanya memerlukan waktu 1 (satu) hari.

2. Detoksifikasi

Tahapan ini merupakan tindak lanjut dari tahapan Intake process. Di sini residen akan mengikuti proses detoksifikasi untuk membersihkan pengaruh dari zat-zat adiktif dengan beberapa metode seperti Symptomatic Pharmacotherapy dan Ultra Rapid Opiod Detoxification (UROD). Proses detoksifikasi ini dilakukan selama 2 (dua) minggu.

3. Entry (Orientasi/Induction)

Pada tahapan ini residen akan dijelaskan dan adaptasi mengenai lingkungan dan berbagai aturan-aturan yang ada di tempat rehabilitasi. Tahapan ini dilakukan selama 2 (dua) minggu pula.

\section{Primary Stage}

Pada tahapan ini terdapat 3 (tiga) proses yang harus dijalani oleh residen, yaitu younger member, middle peer, dan older member. Pada proses younger member, ada empat poin yang akan didapatkan oleh residen seperti penanaman nilai disiplin dalam diri residen, pengenalan diri sendiri dan sesama anggota kelompok, pengenalan konsep dan pembelajaran pola hidup sehat, dan pemberian peran dan tugas dalam ikatan kelompok untuk menumbuhkan rasa tanggung jawab pada diri sendiri. Proses ini akan berjalan selama dua bulan. Setelah menjalani proses younger member maka residen akan melanjutkan ke tahapan selanjutnya yaitu proses middle peer. Pada proses ini residen akan melakukan pemantapan kedisplinan diri, peningkatan rasa percaya diri dalam anggota kelompok dan kemampuan berkomunikasi dengan sesama anggota kelompok, pemantapan pola hidup sehat, pemberian peran dan tugas dalam ikatan kelompok menumbuhkan rasa tanggung jawab bersama (Teamwork Building), dan pemantapan pengendalian diri. Residen akan menjalani proses ini selama satu bulan. Proses terakhir pada tahapan Primary Stage adalah Older Member. Pada proses ini residen akan melakukan penguatan kedisplinan diri menjadi suatu kebutuhan bukan sebagai pemaksaan, pengenalan residen yunior, penguatan pola hidup sehat menjadi bagian dari kepribadiannya, penguatan kerjasama dalam kelompok dan kehidupan sosial internal tempat rehabilitasi sebagai tahapan awal kehidupan bermasyarakat, dan pemberian peran dan tugas dalam pelaksanaan operasional tertentu tempat rehabilitasi dan pembinaan kepada residen yunior. Residen akan menjalani proses ini selama satu bulan.

\section{Re-Entry Stage}

Tahapan ini juga terbagi menjadi tiga bagian yaitu tahap "A", tahap "B", dan tahap " $C$ ". Pada tahap " $A$ " residen akan melakukan tes bakat dan minat, 
workshop atau outbound untuk menyiapkan mental dan percaya diri, dan pelatihan penyusunan rencana. Tahap ini akan dilakukan selama satu minggu. Tahap selanjunnya adalah tahap "B", pada tahapan ini dititikberatkan pada pelaksanaan rencana kegiatan yang telah disusun pada tahapan sebelumnya dan akan didampingi oleh konseler atau pekerja sosial. Evaluasi juga akan dilaksanakan setiap hari setelah kegiatan tersebut terlaksana. Pada tahapan ini residen juga diperbolehkan untuk dikunjungi oleh keluarga yang dapat dilakukan sewaktu-waktu bahkan residen pun dapat pulang menginap bersama keluarga paling banyak empat kali. Namun selama pulang menginap residen akan diberikan buku saku untuk menuliskan berbagai kegiatannya selama pulang menginap yang diketahui oleh salah satu anggota keluarga. Tahap ini akan dijalankan selama satu minggu. Tahapan terakhir adalah tahap "C", pada tahapan ini dititikberatkan kepada pelaksanaan evaluasi secara menyeluruh, sosialisasi program pasca rehabilitasi. Pada tahap ini residen juga diperbolehkan untuk mendapat kunjungan dan pulang menginap bersama keluarga.

Jika diakumulasikan maka residen akan menjalani rehabilitasi selama enam bulan. Residen juga diharuskan melaksanakan semua tahapan tersebut, namun tidak semua residen menjalani proses rehabilitasi selama enam bulan. Hal ini juga dikemukakan oleh Bapak A dalam wawancara yang dilakukan peneliti pada tanggal 10 Juli 2018 di Balai Rehabilitasi BNN Kabupaten Bogor, yang menyatakan bahwa: 15

"Semua residen harus menjalani tahapan rehabilitasi dan itu dijalankan bisa selama kurang dari enam bulan ada juga yang lebih, tergantung hasil

${ }^{15}$ Hasil wawancara dengan Bapak A selaku residen di Balai Rehabilitasi BNN Kabupaten Bogor, pada tanggal 10 Juli 2018. asessment dan kemauan dari orangnya untuk sembuh."

Selain program rehabilitisi, Balai Rehabilitasi BNN Kabupaten Bogor juga memiliki program pasca rehabilitasi. Program ini diberikan kepada residen yang telah melakukan rehabilitasi dan belum memiliki pekerjaan tetap. Pada program ini residen akan dibekali keterampilan dan pengalaman agar nantinya dapat mendapatkan pekerjaan setelah keluar dari Balai Rehabilitasi BNN Kabupaten Bogor. Ada beberapa tahap yang harus dijalankan oleh residen pada program pasca rehabilitasi ini. Tahap tersebut adalah:

1. Tahap Orientasi Program

Tahap ini merupakan tahap persiapan residen rentry menuju program pasca rehabilitasi. Tahap ini ditujukan untuk memberikan pembekalan dan pengenalan program sesuai jenis program yang ada serta menjadikan residen terbiasa dengan kondisi lingkungan. Kegiatan pada tahap ini diarahkan pada:

a. Penyiapan mental dan percaya diri;

b. Pemantapan disiplin diri yang sudah dibektuk dalam tempat rehabilitasi; dan

c. Pengenalan kondisi lingkungan termasuk tata tertib yang berlaku.

Tahap ini akan dijalani oleh residen selama dua minggu.

2. Tahap Pelatihan dan Praktik

Tahap ini ditujukan untuk memberikan berbagai keterampilan residen dan dilanjutkan dengan praktik sampai memperoleh dasil yang diharapkan. Kegiatan pada tahap ini diarahakan pada:

a. Pemberian keterampilan sesuai bakat dan minat;

b. Praktik sesuai keterampilan yang diberikan; dan

c. Integrasi sosial dengan masyarakat sekitar.

Tahap ini akan dijalani oleh residen selama empat minggu.

3. Tahap Evaluasi Hasil dan Penyiapan Praktik Kerja Lapangan. 
Tahap ini ditujukan untuk melakukan evaluasi secara menyeluruh dan penyiapan residen memasuki kehidupan yang sesungguhnya dengan berbekal keterampilan yang telah dimiliki selama mengikuti program pasca rehabilitasi. Tahap ini merupakan tahap terakhir pasca rehabilitasi menuju rumah dampingan.

4. Rumah Dampingan

Pada tahap ini residen tinggal di rumah dampingan dengan sesama residen paling banyak berjumlah 10 (sepuluh) orang yang didampingi konselor atau pekerja sosial atau tenaga medis. Pada tahap ini secara berkala residen juga akan mengikuti tes urine. Beberapa kegiatan yang bisa diikuti residen adalah:

a. Bekerja di Perusahaan;

b. Usaha Mandiri Produktif; dan

c. Usaha jasa.

5. Rumah Mandiri

Hampir sama dengan rumah dampingan, tahap ini residen juga akan tinggal di rumah mandiri bersama residen yang berjumlah maksimal 10 (sepuluh) orang. Namun pada tahap ini residen tidak lagi dimpingi oleh konselor atau pekerja sosial atau tenaga medis setiap hari melainkan hanya dua kali seminggu saja. Tahap ini tetap akan diadakan tes urine secara berkala. Kegiatan yang diikuti oleh residen juga sama seperti tahap sebelumnya yaitu:

a. Bekerja di Perusahaan;

b. Usaha Mandiri Produktif; dan

c. Usaha jasa.

Berdasarkan jenisnya narkotika telah terbagi dari 3 (tiga) golongan sesuai tingkat ketergantungan. Jika dilihat dari jenisnya, ada beberapa jenis narkotika yang paling sering digunakan. Adapun jenis narkotika yang paling sering digunakan oleh pecandu dan korban penyalahgunaan narkotika, sebagai berikut:

TABEL 2

JUMLAH RESIDEN BERDASARKAN ZAT YANG DIPAKAI

\begin{tabular}{|c|c|c|c|c|c|c|}
\hline \multirow[t]{2}{*}{ NO. } & \multirow[t]{2}{*}{ JENIS } & \multicolumn{5}{|c|}{ JUMLAH RESIDEN } \\
\hline & & 2013 & 2014 & 2015 & 2016 & 2017 \\
\hline 1. & Shabu & 64 & 183 & 31 & 26 & 121 \\
\hline 2. & Ganja & 7 & 37 & 16 & 2 & 1 \\
\hline 3. & Putauw & 1 & 3 & 0 & 0 & - \\
\hline 4. & Inex & 1 & 7 & 0 & 0 & - \\
\hline 5. & Destro & 3 & 2 & 0 & 0 & - \\
\hline 6. & Tramadol & 2 & 21 & 1 & 1 & 3 \\
\hline 7. & $>1 \mathrm{Zat}$ & 42 & 83 & 141 & 112 & 7 \\
\hline & umlah & 120 & 339 & 189 & 141 & 132 \\
\hline
\end{tabular}

Sumber : BNN Kabupaten Bogor Tahun 2017.

Data di atas menunjukkan bahwa narkotika jenis shabu merupakan salah satu jenis yang paling banyak digunakan. Selain itu jumlah pecandu dan korban penyalahgunaan narkotika yang menggunakan lebih dari 1 zat juga sangat tinggi. Hal ini membuktikan bahwa masih banyak orang yang tertarik untuk menggunakan narkotika.

Seperti yang kita ketahui bersama, narkotika seharusnya dapat menjadi salah satu obat yang bermanfaat untuk kesehatan jika dikaji dari segi medis. Namun, seiring keberadaannya narkotika saat ini tidak hanya menjadi obat melainkan menjadi salah satu masalah yang tidak ada habisnya. Banyaknya elemen yang terlibat dalam peredaran narkotika ini menjadikan sulit untuk diberantas, tidak hanya warga asing yang menjadi pengedarnya bahkan tidak jarang juga aparat kepolisian yang melakukan transaksi pengedaran ataupun sebagai pemakai.

Pada perkembangannya, korban penyalahgunaan narkotika semakin tahun semakin meningkat dan tidak lagi memandang umur orang tersebut, pasien pengguna narkotika dapat dilihat pada tabel di bawah ini:

TABEL 3

\section{RESIDEN BERDASARKAN KELOMPOK USIA PENGGUNA NARKOTIKA KABUPATEN BOGOR}

\begin{tabular}{|c|c|c|c|c|c|c|}
\hline \multirow{2}{*}{ NO. } & \multirow{2}{*}{ USIA } & \multicolumn{4}{|c|}{ JUMLAH RESIDEN } & \multirow{2}{*}{ TOTAL } \\
\cline { 3 - 6 } & $\mathbf{2 0 1 4}$ & $\mathbf{2 0 1 5}$ & $\mathbf{2 0 1 6}$ & $\mathbf{2 0 1 7}$ & \\
\hline 1. & $\begin{array}{l}<16 \\
\text { tahun }\end{array}$ & 4 & 15 & 2 & 1 & 22 \\
\hline 2. & $\begin{array}{l}16-20 \\
\text { tahun }\end{array}$ & 26 & 76 & 46 & 39 & 187 \\
\hline 3. & $21-25$ & 32 & 76 & 37 & 29 & 174 \\
\hline
\end{tabular}




\begin{tabular}{|c|c|c|c|c|c|c|}
\hline 4. & $\begin{array}{l}\text { tahun } \\
\begin{array}{|}26-30 \\
\text { tahun }\end{array}\end{array}$ & 32 & 67 & 34 & 31 & 164 \\
\hline 5. & $\begin{array}{l}31-35 \\
\text { tahun }\end{array}$ & 18 & 64 & 41 & 25 & 148 \\
\hline 6. & $\begin{array}{l}36-40 \\
\text { tahun }\end{array}$ & 4 & 21 & 19 & 9 & 53 \\
\hline 7. & $\begin{array}{l}>40 \\
\text { tahun }\end{array}$ & 4 & 17 & 10 & 7 & 38 \\
\hline \multicolumn{2}{|c|}{ Jumlah } & $\mathbf{1 2 0}$ & $\mathbf{3 3 9}$ & $\mathbf{1 8 9}$ & $\mathbf{1 4 1}$ & $\mathbf{7 8 9}$ \\
\hline
\end{tabular}

Sumber : BNN Kabupaten Bogor Tahun 2017.

Berdasarkan data di atas menunjukkan bahwa kelompok usia 16-20 paling banyak menggunakan narkotika. Bahaya dari penyalahgunaan narkotika tersebut dapat berdampak pada pribadi si pemakai dan dapat pula berbahaya pada lingkungan sosial terhadap masyarakat dan lingkungan. Dampak yang ditimbulkan dari pemakaiannyapun tidak main-main, ketergantungan psikis yang diikuti oleh kecanduan fisik dalam waktu lama, peningkatan depresi, berhalusinasi, hingga mengakibatkan penyakit kronis bahkan kematian. Semakin banyak orang yang memilih menggunakan narkotika sebagai jalan singkat untuk setiap masalah yang dihadapi menjadikan keberadaan narkotika semakin subur, karena hal itulah, maka tidak jarang pecandu yang menggunakan narkotika tidak serta merta dapat bebas dari narkotika. Dilihat dari keadaannya banyak faktor yang mendukung seseorang untuk menggunakan narkotika baik secara sengaja maupun tidak sengaja.

Sedangkan data yang ada di lembaga rehabilitasi BNN Kabupaten Bogor menunjukkan data yang tidak jauh berbeda dengan apa yang menjadi data otentik pihak Badan Narkotika Nasional Kabupaten Bogor. Lihat data di bawah ini:

TABEL 4

JUMLAH PENYALAHGUNA NARKOBA DI BALAI REHABILITASI KABUPATEN BOGOR BERDASARKAN KELOMPOK USIA TAHUN 2017

\begin{tabular}{|c|c|c|c|c|}
\hline NO. & $\begin{array}{c}\text { KELOMPOK } \\
\text { USIA }\end{array}$ & \multicolumn{2}{|c|}{ JENIS KELAMIN } & JUM \\
\cline { 3 - 4 } & & $\begin{array}{c}\text { LAKI- } \\
\text { LAKI }\end{array}$ & $\begin{array}{c}\text { PEREM } \\
\text { PUAN }\end{array}$ & \\
\hline 1. & $<15$ Tahun & - & - & - \\
\hline 2. & $15-20$ Tahun & 73 & 3 & 76 \\
\hline 3. & $21-25$ Tahun & 63 & 10 & 73 \\
\hline 4. & $26-30$ Tahun & 53 & 8 & 61 \\
\hline
\end{tabular}

\begin{tabular}{|c|l|c|c|c|}
\hline 5. & $31-35$ Tahun & 54 & 6 & 60 \\
\hline 6. & $36-40$ Tahun & 26 & 3 & 29 \\
\hline 7. & $>40$ Tahun & 16 & - & 16 \\
\hline 8. & Tidak Terdata & - & - & - \\
\hline & Jumlah & $\mathbf{2 8 5}$ & $\mathbf{3 0}$ & $\mathbf{3 1 5}$ \\
\hline
\end{tabular}

Sumber : Balai Rehabilitasi Kabupaten Bogor Tahun 2017.

Pada Balai Rehabiltasi BNN Kabupaten Bogor masih menunjukkan data yang sama di tahun 2017. Dimana usia 15-20 Tahun masih terhitung terbanyak dari usia lainnya. Penggunaan narkotika yang berlebihan dapat mengakibatkan ketergantungan pada si pemakai sehingga pecandu tersebut tidak mudah lepas dari penggunaan narkotika, pecandu berdasarkan Pasal 1 angka 13 Undangundang Nomor 35 Tahun 2009 tentang Narkotika menjelaskan bahwa:

"Pecandu narkotika merupakan orang yang menggunakan atau menyalahgunakan narkotika dan dalam keadaan ketergantungan pada narkotika, baik secara fisik maupun psikis."

Sedangkan ketergantungan pada suatu narkotika terdapat dalam Pasal 1 angka 14 Undang-undang Nomor 35 Tahun 2009 tentang Narkotika menjelaskan bahwa:

"Ketergantungan narkotika adalah kondisi yang ditandai oleh dorongan untuk menggunakan narkotika secara terus-menerus dengan takaran yang meningkat agar menghasilkan efek yang sama dan apabila penggunaannya dikurangi dan/atau dihentikan secara tiba-tiba, menimbulkan gejala fisik dan psikis yang khas".

Dalam permasalahan narkotika, peran keluarga sangat diperlukan terhadap perkembangan seorang anak sehingga menjadi acuan terhadap individu-individu yang terjerumus dalam permasalahan narkotika ini. Keluarga seharusnya menjadi hal terpenting dalam pencegahan dan pengawasan dalam menggunakan narkotika. Pengawasan dari orang tua menjadi sangat penting karena dengan pengontrolan yang baik dari orang tua tentunya dapat membatasi gerak dari anak ataupun anggota keluarga lain untuk tidak terjerumus dalam permasalahan narkotika. Namun ada pula orang yang menggunakan 
narkotika ini berawal pada permasalahan keluarga, mulai dari perceraian yang terjadi pada orang tuanya sampai kurangnya perhatian yang dia dapatkan sehingga memilih menggunakan narkotika agar mendapatkan perhatian dari orang tuanya.

Meningkatnya kejahatan narkotika ini pada umumnya disebabkan 2 (dua) hal, yaitu: pertama, bagi para pengedar menjanjikan keuntungan yang besar, sedangkan bagi para pemakai menjanjikan ketentraman dan ketenangan hidup, sehingga beban psikis yang dialami dapat dihilangkan. Kedua, janji yang diberikan narkotika itu menyebabkan rasa takut terhadap resiko tertangkap menjadi berkurang, bahkan sebaliknya akan menimbulkan rasa keberanian. Hal ini menunjukkan bahwa kondisi ekonomi pun dapat mempengaruhi seseorang untuk menggunakan narkotika. Jumlah residen yang ada di Balai Rehabilitasi BNN Kabupaten Bogor sesuai tingkatan pendidikan dapat dilihat pada tabel berikut ini:

TABEL 5

JUMLAH PENYALAHGUNA NARKOBA DI BALAI REHABILITASI BNN KABUPATEN BOGOR BERDASARKAN TINGKAT PENDIDIKAN TAHUN 2017

\begin{tabular}{|c|l|c|c|c|}
\hline NO. & \multirow{2}{*}{$\begin{array}{c}\text { KELOMPOK } \\
\text { USIA }\end{array}$} & \multicolumn{2}{|c|}{ JENIS KELAMIN } & JUMLAH \\
\cline { 3 - 4 } & & $\begin{array}{c}\text { LAKI- } \\
\text { LAKI }\end{array}$ & PEREMPUAN & \\
\hline 1. & SD & 12 & - & 12 \\
\hline 2. & SMP & 45 & 7 & 52 \\
\hline 3. & SMA & 176 & 20 & 196 \\
\hline 4. & Akademi & 22 & 1 & 23 \\
\hline 5. & $\begin{array}{l}\text { Perguruan } \\
\text { Tinggi }\end{array}$ & 30 & 1 & 31 \\
\hline 6. & $\begin{array}{l}\text { Tidak } \\
\text { Terdata }\end{array}$ & - & - & - \\
\hline \multicolumn{2}{|l}{ Jumlah } & $\mathbf{2 8 5}$ & $\mathbf{2 9}$ & $\mathbf{3 1 4}$ \\
\hline
\end{tabular}

Sumber: Balai Rehabilitasi Kabupaten Bogor Tahun 2017.

Hampir setiap hari media menyiarkan beberapa berita tentang kasus peredaran gelap narkotika itu sendiri hingga narkotika itu tidak memandang status pekerjaan seseorang. Baik itu tingkatan penghasilan rendah ke menengah hingga penghasilan menengah ke penghasilan yang tinggi. Hal ini membuktikan bahwa narkotika tidak memandang apapun pekerjaan seseorang. Dari penelitian yang saya lakukan data yang diberikan Balai Rehabilitasi BNN Kabupaten Bogor menujukkan data sebagai berikut:

TABEL 6

JUMLAH RESIDEN YANG ADA DI BALAI REHABILITASI BNN KABUPATEN BOGOR SESUAI STATUS PEKERJAANNYA.

\begin{tabular}{|c|l|c|c|c|}
\hline NO. & \multirow{2}{*}{$\begin{array}{c}\text { KELOMPOK } \\
\text { USIA }\end{array}$} & \multicolumn{2}{|c|}{ JENIS KELAMIN } & JUML \\
\cline { 3 - 4 } & & $\begin{array}{c}\text { LAKI- } \\
\text { LAKI }\end{array}$ & $\begin{array}{c}\text { PEREM } \\
\text { PUAN }\end{array}$ & \\
\hline 1. & Pelajar & 38 & 2 & 40 \\
\hline 2. & Mahasiswa & - & - & - \\
\hline 3. & TidakBekerja & 94 & 19 & 113 \\
\hline 4. & $\begin{array}{l}\text { Buruh (Tani, } \\
\text { Tukang, dsb) }\end{array}$ & 12 & - & 12 \\
\hline 5. & PNS & 8 & - & 8 \\
\hline 6. & TNI/ POLRI & 10 & - & 10 \\
\hline 7. & Swasta & 21 & 1 & 22 \\
\hline 8. & Wiraswasta & 102 & 8 & 130 \\
\hline \multicolumn{2}{|l|}{ Jumlah } & $\mathbf{2 8 5}$ & $\mathbf{3 0}$ & $\mathbf{3 1 5}$ \\
\hline
\end{tabular}

Sumber : Balai Rehabilitasi Kabupaten Bogor Tahun 2017.

Data di atas menunjukkan peredaran gelap narkotika merambah semua jenis pekerjaan. Wiraswata masih bertender di posisi pertama disusul dengan tidak bekerja (pengangguran). Ini membuktikan bahwa cenderung pemakai atau korban penyalahgunaan narkotika bermotif cobacoba diperjelas oleh salah satu residen yang diwawancarai oleh penulis sendiri menggungkapkan:

"Pada awalnya saya hanya mencoba ketika ditawari oleh teman, rasa penasaran (keingintahuan saya yang tinggi) akhirnya saya terjerumus satu kali mencoba, kemudian esok lagi dan akhirnya ketagihan barang tersebut."

Penyalahgunaan narkotika seharusnya dapat diberantas. Namun, karena permasalahannya sangat kompleks yang disebabkan oleh beberapa faktor sehingga upaya penanggulangan yang dapat dilakukan yaitu dengan upaya komprehensif dan terpadu. Penyebaran informasi yang tepat akan bahaya narkotika dan penyuluhan adalah salah satu upaya pencegahan yang dapat 
ditempuh untuk memberantas narkotika. Pada pembahasan ini penulis akan menguraikan faktor-faktor apa saja yang dapat membuat seseorang dapat menggunakan narkotika. Terdapat 5 (lima) faktor pendorong orang menggunakan narkotika:

1. Faktor Ketidaktahuan

Walaupun kejahatan narkotika merupakan hal yang harus diberantas namun ada beberapa hal yang harus kita perhatikan. Faktor ketidaktahuan ini merupakan salah satu faktor yang tidak sedikit orang alami. Pengetahuan masyarakat yang kurang terhadap narkotika menjadi dasar faktor ini dapat menjadikan seseorang untuk menggunakan narkotika. Dalam hal inilah orang tersebut diketegorikan sebagai korban penyalahgunaan narkotika. Faktor ini merupakan faktor di mana seseorang sebetulnya tidak menginginkan untuk terjebak dalam permasalahan narkotika, namun dengan ketidaktahuannyalah yang menjerumuskannya kepenggunaan narkotika dan pada akhirnya mengalami ketergantungan.

2. Faktor Coba-coba

Orang yang mencoba-coba untuk menyalahgunakan narkotika biasanya memiliki sedikit pengetahuan tentang narkotika, bahaya yang ditimbulkan serta aturan hukum yang melarang menyalahgunakan narkotika. Pada kondisi ini, pecandu menggunakan narkotika karena berdasar rasa ingin tahu yang tinggi, meskipun telah mengetahui dampak yang ditimbulkan dari penggunaannya. Biasanya orang yang berada pada titik/situasi ini adalah remaja atau anak-anak yang masih memiliki rasa ingin tahu yang tinggi.

3. Faktor Keluarga

Mungkin, dalam suatu keluarga kerap kali mengalami konflik yang berakibatkan seseorang mengalami frustasi atau orang tua terlalu sibuk sehingga jarang mempunyai waktu untuk mengontrol anggota keluarga. Sehingga anak tersebut mencari jalan agar mendapatkan perhatian dari kedua orang tuanya dengan cara menggunakan narkotika. Hal ini dapat terjadi karena seorang anak cenderung memiliki tingkat emosi yang labil sehingga dalam pengambilan keputusan dia tidak mempertimbangkan baik buruknya terlebih dahulu yang pada akhirnya keputusan yang dia lakukan akan berdampak besar untuk kehidupannya. Untuk itu pengawasan dan perhatian dari orang tua sangat berpengaruh untuk perkembangan anak.

4. Faktor Ekonomi

Pada faktor ini, seseorang yang terjerumus menggunakan narkotika yaitu seseorang yang berada pada tingkat ekonomi yang rendah sampai tinggi. Terkhusus bagi orang yang memiliki kondisi ekonomi yang rendah biasanya menggunakan narkotika karena tidak sanggup lagi menahan beban hidupnya yang sulit. Narkotika dijadikan sebagai jalan pintas untuk melupakan semua permasalahan yang membebaninya. Sedangkan bagi orang yang memiliki ekonomi yang tinggi dapat dengan mudah untuk membeli narkotika sesuka hatinya. Dengan begitu banyaknya peredaran narkotika, maka dengan mudah orang tersebut mendapatkan narkotika. Sehingga ekonomi tinggi dan rendah juga memiliki peluang yang tinggi untuk menggunakan narkotika.

5. Faktor Lingkungan

Faktor yang terakhir adalah faktor lingkungan di mana remaja tidak hanya hidup di lingkungan keluarga ataupun sekolah melainkan juga dalam masyarakat yang luas. Dengan semakin bebasnya pergaulan anak muda masa kini ditambah dengan berkurangnya moral dari generasi mudah kita sehingga ada peluang seseorang terjerumus menggunakan narkotika dikarenakan faktor lingkungan. 
Terlebih lagi rasa persatuan yang tinggi dalam suatu kelompok menjadikan seseorang diharuskan melakukan apa yang dilakukan oleh anggota kelompok tersebut. Oleh karena itu, kondisi dalam masyarakat juga mempengaruhi perilaku remaja, termaksud perilaku yang berkaitan dengan penyalahgunaan narkotika.

\section{B. PELAKSANAAN ASSESMEN TENTANG REHABILITASI TERHADAP KORBAN PENYALAHGUNAAN NARKOTIKA DITINJAU DARI PERATURAN PERUNDANG-UNDANGAN}

Seorang pecandu dan korban penyalahgunaan narkotika merupakan korban dari narkotika sehingga ia pantas disebut sebagai orang sakit. Akibat, seorang pecandu dan korban penyalahgunaan narkotika wajib menjalani pengobatan dengan memasukannya ke lembaga rehabilitasi medis dan/atau rehabilitasi sosial.

Penempatan pecandu dan korban penyalahgunaan narkotika ke dalam lembaga rehabilitasi tersebut sesuai dengan tujuan undang-undang sebagaimana telah diamanatkan dalam Pasal 4 huruf d Undang-undang Nomor 35 Tahun 2009 tentang Narkotika. Pecandu dan korban penyalahgunaan narkotika. Selain itu, Pasal 127 Undang-undang Nomor 35 Tahun 2009 tentang Narkotika juga dijadikan pedoman oleh hakim dalam menjatuhkan putusan rehabilitasi kepada pecandu dan korban penyalahgunaan narkotika (walaupun tidak wajib) dengan memperhatikan ketentuan Pasal 54, Pasal 55 dan Pasal 103 Undang-undang Nomor 35 Tahun 2009 tentang Narkotika. Undangundang Nomor 35 Tahun 2009 tentang Narkotika secara spesifik penempatan rehabilitasi bagi pecandu dan penyalahgunaan narkotika yang sedang dalam proses hukum juga diatur dalam Pasal 13 ayat (4) sampai dengan ayat (6) Peraturan Pemerintah Nomor 25 Tahun 2011 tentang Pelaksanaan Wajib Lapor Pecandu Narkotika, berbunyi:
"(4) Penempatan dalam $\begin{gathered}\text { lembaga } \\ \text { rehabilitasi }\end{gathered}$ medis
dan/atau rehabilitasi sosial sebagaimana dimaksud pada ayat (3) merupakan kewenangan penyidik, penuntut umum, atau hakim sesuai dengan tingkat pemeriksaan setelah mendapatkan rekomendasi dari Tim Dokter.

(5) Ketentuan penempatan dalam lembaga rehabilitasi medis dan/atau rehabilitasi sosial sebagaimana dimaksud pada ayat (3) dan ayat (4) berlaku juga bagi korban penyalahgunaan narkotika.

(6) Ketentuan lebih lanjut mengenai pelaksanaan penempatan dalam lembaga rehabilitasi medis dan/atau rehabilitasi sosial sebagaimana dimaksud pada ayat (3), ayat (4), dan ayat (5) diatur oleh menteri setelah berkoordinasi dengan instansi terkait".

Munculnya assesmen sebagai sarana untuk memperoleh informasi terkait narkotika dari pecandu dan korban penyalahguna narkotika dengan membentuk tim assesmen terpadu yang dilandasi oleh Peraturan Bersama Ketua Mahkamah Agung Republik Indonesia, Menteri Hukum dan Hak Asasi Manusia Republik Indonesia, Menteri Kesehatan Republik Indonesia, Menteri Sosial Republik Indonesia, Jaksa Agung Republik Indonesia, Kepala Kepolisian Negara Republik Indonesia dan Kepala Badan Narkotika Nasional Republik Indonesia Nomor: 01/PB/MA/III/2014, Nomor: 03 Tahun 2014, Nomor: 11/Tahun 2014, Nomor: 03 Tahun 2014, Nomor: PER005/A/JA/03/2014, Nomor: 1 Tahun 2014, Nomor: $\quad$ PERBER/01/III/2014/BNN tentang Penanganan Pecandu Narkotika dan Korban Penyalahgunaan Narkotika ke Dalam Lembaga Rehabilitasi. Pecandu dan penyalahgunaan narkotika yang telah memasuki wilayah hukum perlu tindakan yang cermat dan hati-hati melalui proses assesmen terlebih dahulu dalam menentukan layak atau tidak pecandu dan 
penyalahgunaan narkotika yang telah ditetapkan sebagai tersangka dan/atau terdakwa untuk ditempatkan ke dalam lembaga rehabilitasi medis dan/atau rehabilitasi sosial. Secara singkat tujuan dari assesmen ialah untuk mengetahui sejauhmana tingkat kecanduan dan peran pecandu dan penyalahgunaan narkotika dalam kejahatan narkotika. ${ }^{16}$

Tindakan assesmen yang berujung pada rehabilitasi sudah dapat dimulai pada tahapan penyidikan. Kewenangan untuk melakukan penyidikan terhadap kejahatan narkotika ialah Badan Narkotika Nasional (BNN) dan Kepolisian Negara Republik Indonesia. ${ }^{17}$ Proses assesmen yang terjadi pada tahapan penyidikan baik yang dilakukan oleh BNN dan Kepolisian ialah sama. ${ }^{18}$ Kesamaan tersebut disebabkan karena polisi dan BNN (Kejaksaan dan Kementerian Hukum dan HAM) tergabung dalam tim hukum yang terdapat pada tim assesmen terpadu.

Sejak diberlakukan Peraturan Bersama di atas, proses penyidikan narkotika di kepolisian terhadap pecandu yang melaporkan diri akan direkomendasikan untuk mendatangi Institusi Penerima Wajib Lapor (IPWL) untuk dilakukan assesmen untuk menentukan taraf kecanduannya sebagai penentu waktu rehabilitasinya. ${ }^{19}$

16 Pasal 18 ayat (4) Peraturan Kepala Badan Narkotika Nasional No. 11 Tahun 2014 tentang Tata Cara Penanganan Tersangka dan/atau Terdakwa Pecandu Narkotika dan Korban Penyalahgunaan Narkotika ke Dalam Lembaga Rehabiliasi, berbunyi: Rekomendasi sebagaimana dimaksud pada ayat (3) disampaikan kepada Penyidik yang meliputi: 1) Peran tersangka sebagai: a) Pecandu dengan tingkat ketergantungannya terhadap Narkotika; b) Pecandu merangkap sebagai pengedar atau terlibat dalam jaringan peredaran gelap Narkotika; dan c) Korban Penyalahgunaan Narkotika. 2) Rencana rehabilitasi sesuai dengan tingkat ketergantungan narkotika.

17 Ibid.

18Wawancara dengan Kepala Badan Narkotika Nasional Kabupaten Bogor, Pada tanggal 7 Maret 2018.

${ }^{19}$ Dani Krinawati \& Niken Subekti Budi Utami, Pelaksanaan Rehabilitasi Bagi Pecandu Narkotika Pada Tahap Penyidikan Pasca Berlakunya Peraturan Bersama 7 (Tujuh) Lembaga Negara Republik
Hal ini tidak dilakukan oleh kepolisian ketika menangkap seorang tersangka kasus narkotika. Terhadap kasus tersebut, kepolisian terlebih dahulu akan menyerahkan tersangka kepada tim assesmen terpadu untuk dapat ditentukan taraf kecanduannya dan untuk menentukan seseorang tersebut memang layak untuk mendapatkan tindakan rehabilitasi. Hal tersebut sesuai dengan Pasal 8 ayat (3) Peraturan Kepala Badan Narkotika Nasional Nomor 11 Tahun 2014 tentang Tata Cara Penanganan Tersangka dan/atau Terdakwa Pecandu Narkotika dan Korban Penyalahgunaan Narkotika ke Dalam Lembaga Rehabiliasi, berbunyi:20

"Assesmen sebagaimana yang dimaksud pada ayat (2) dilaksanakan berdasarkan permohonan penyidik kepada tim assesmen terpadu".

Seorang yang dilakukan penangkapan terhadap dirinya atas tindak pidana narkotika jika penyidik memohonkan asesmen maka mekanisme pelaksanaan asesmen oleh tim asesmen terpadu, yaitu:

1. Tim assesmen terpadu melaksanakan asesmen atas permohonan tertulis dari penyidik. Penyidik mengajukan permohonan paling lama 1 x 24 (satu kali dua puluh empat jam) setelah penangkapan. Tim assesmen memiliki tugas sebagaimana telah dituliskan dalam Bab II Sub bab A angka 3, yaitu:

a. Assesmen dan analisis medis, psikologi, serta merekomendasi rencana terapi dan rehabilitasi seseorang yang ditangkap dan/atau tertangkap tangan. Assesmen dilakukan oleh minimal 2 (dua) orang anggota tim medis. Assesmen yang dimaksud pada tahapan ini meliputi:

1) Wawancara, tentang riwayat kesehatan, riwayat penggunaan narkotika, riwayat pengobatan dan perawatan,

Indonesia, Yogyakarta: Hasil Penelitian Fakultas Hukum Universitas Gadjah Mada, 2014, Hlm. 28.

${ }^{20}$ Pasal 8, Op.Cit., Peraturan Kepala Badan Narkotika Nasional No. 11 Tahun 2014. 
riwayat psikiatris, serta riwayat keluarga dan sosial tersangka dan/atau terdakwa;

2) Observasi atas perilaku tersangka; dan

3) Pemeriksaan fisik dan psikis. ${ }^{21}$ Hasil pemeriksaan tim dokter di atas dituangkan dalam bentuk hasil assesmen tim dokter untuk kepentingan peradilan dan ditandatangani oleh tim dokter yang melakukan assesmen. Hasil assesmen tim dokter menjadi bahan rekomendasi tim asesmen terpadu yang berisi tingkat ketergantungan penyalahgunaan narkotika, tempat dan lama rehabilitasi sesuai dengan rencana terapi. $^{22}$

b. Analisis terkait dengan seseorang yang ditangkap dan/atau tertangkap tangan dalam kaitan peredaran gelap narkotika dan penyalahgunaan narkotika. Assesmen dilakukan oleh minimal 2 (dua) orang anggota tim hukum. Assesemen yang dimaksud pada tahapan ini meliputi:

1) Pencocokkan identitas Tersangka, antara lain: photo, sidik jari, ciri- ciri fisik, dan nama/alias, dengan data jaringan Narkotika yang ada di database BNN dan Polri;

2) Analisis data intelijen terkait, jika ada;

3) Riwayat keterlibatan pada tindak kriminalitas;

4) Menelaah Berita Acara Pemeriksaan Tersangka yang terkait dengan perkara lainnya; dan

${ }^{21 B a d a n}$ Narkotika Nasional, Petunjuk Teknis Pelaksanaan Assesmen Terpadu Bagi Pecandu dan Korban Penyalahgunaan Narkotika Dalam Poses Hukum, Jakarta: Deputi Bidang Rehabilitasi Badan Narkotika Nasional, 2015, Hlm. 4.

22 Ibid.
5) Telaahan penerapan pasalpasal Undang-undang Nomor 35 Tahun 2009 tentang Narkotika dan Surat Edaran Mahkamah Agung Nomor 4 Tahun 2010 tentang Penempatan Penyalah Guna Narkotika ke Dalam Lembaga Rehabilitasi Medis dan Rehabilitasi Sosial dan Surat Edaran Jaksa Agung Nomor SE002/A/JA/02/2013 tentang Penempatan Korban Penyalahgunaan Narkotika ke Lembaga Rehabilitasi Medis dan Rehabilitasi Sosial. 23

6) Hasil analisis tim hukum dituangkan dalam bentuk hasil assesmen sesuai dengan format instrumen hukum untuk kepentingan peradilan dan ditandatangani oleh tim hukum yang melakukan assesmen. Hasil assesmen tim hukum menjadi bahan rekomendasi tim assesmen terpadu berupa status tersangka dan/atau terdakwa dan kelanjutan proses hukumnya. 24

2. Petugas sekretariat tim assesmen menyampaikan surat pemberitahuan pelaksanaan assesmen kepada pimpinan langsung di instansi masingmasing sesuai dengan pengajuan assesmen. Dalam mendukung pelaksanaan tugas tim assesmen terpadu diperlukan sekretariat dan petugas administrasi 2 (dua) orang yang ditetapkan oleh kepala BNN sesuai dengan tempat dibentuknya tim assesmen terpadu. ${ }^{25}$

3. Tim assesmen terpadu melakukan assesmen maksimal 2x24 (dua kali dua puluh empat) jam, selanjutnya hasil assesmen dari tim dokter dan tim

23 Pasal 16, Op.Cit., Peraturan Kepala Badan Narkotika Nasional No. 11 Tahun 2014.

${ }^{24}$ Badan Narkotika Nasinal, Op.Cit, Hlm. 5.

25 Ibid, Hlm. 6. 
hukum disimpulkan paling lama hari ketiga.

4. Hasil assesmen yang didapat dari masing-masing tim assesmen dibahas pada pertemuan pembahasan kasus (case conference) pada hari keemat untuk ditetapkan sebagai rekomendasi tim assesmen terpadu. Rekomendasi tim assesmen terpadu berisi keterangan mengenai peran tersangka dan/atau terdakwa, tingkat ketergantungan penyalahgunaan narkotika, rekomendasi kelanjutan proses hukumnya dan tempat serta lamanya waktu rehabilitasi. Rekomendasi tim assesmen terpadu ditandatangani oleh ketua tim assesmen terpadu. Demi kepentingan proses pengadilan, hasil rekomendasi tim assesmen terpadu yang dilampirkan pada berkas tersangka harus asli bukan dalam bentuk foto copy. Ketua tim assesmen terpadu memiliki tugas, sebagai berikut:

a. Memimpin pembahasan kasus (case conference), yaitu membahas hasil assesmen tim dokter dan tim hukum yang selanjutnya akan menjadi rekomendasi tim assesmen terpadu,

b. Menandatangani hasil rekomendasi berdasarkan hasil pembahasan kasus. ${ }^{26}$

5. Pelaksanaan assesmen oleh tim dokter dilakukan di Institusi Penerima Wajib Lapor (IPWL) ${ }^{27}$ yang telah ditetapkan oleh Kementerian Kesehatan dan/atau disekretarat tim assesmen terpadu.

\section{${ }^{26}$ Ibid.}

27 Pengaturan Wajib Lapor Pecandu Narkotika bertujuan untuk: a) Memenuhi hak Pecandu Narkotika dalam mendapatkan pengobatan dan/atau perawatan melalui rehabilitasi medis dan rehabilitasi sosial; b) Mengikutsertakan orang tua, wali, keluarga, dan masyarakat dalam meningkatkan tanggung jawab terhadap Pecandu Narkotika yang ada di bawah pengawasan dan bimbingannya; dan c) Memberikan bahan informasi bagi Pemerintah dalam menetapkan kebijakan di bidang pencegahan dan pemberantasan penyalahgunaan dan peredaran gelap Narkotika. (Pasal 2 Peraturan Pemerintah No. 25 Tahun 2011).
Apabila dalam hal kondisi mendesak pemeriksaan dapat dilakukan di kantor penyidik yang mengajukan permohonan.

6. Pelaksanaan assesmen oleh tim hukum dilakukan di sekretariat tim assesmen terpadu dan apabila dalam hal kondisi mendesak pemeriksaan dapat dilakukan di kantor penyidik yang mengajukan permohonan.

7. Guna memperoleh data yang akurat dan mengoptimalkan hasil assesmen maka proses assesmen perlu dilakukan dalam ruangan yang dapat menjaga privasi dan tidak dihadiri oleh pihak ketiga baik keluarga, profesional lain kecuali kasus-kasus tertentu.

8. Tim assesmen terpadu melaksanakan tugasnya dan memberikan rekomendasi hasil assesmen dalam jangka waktu paling lama 6 (enam) hari kepada penyidik untuk dilaporkan tertulis kepada pengadilan negeri setempat. ${ }^{28}$

9. Hasil dari penilaian tim assesmen terpadu merupakan dasar bagi penyidik BNN dalam menentukan seorang tersangka pecandu narkotika direhabilitasi di lembaga rehabilitasi atau ia direhabilitasi di rutan karena posisinya yang tidak hanya sebagai pecandu narkotika namun juga pengedar, kurir, atau bandar.

Evaluasi terhadap masa kerja tim assesmen terpadu dilaksanakan setiap 1 (satu) tahun secara priodik dan apabila dipandang perlu dapat dilakukan kurang dari 1 (satu) tahun. Evaluasi dilakukan oleh tim evaluasi yang terdiri dari perwakilan Badan Narkotika Nasional, Kementerian Kesehatan, Kementerian Sosial, Kejaksaan RI, Kepolisian Republik Indonesia untuk tingkat pusat dan Badan Narkotika Nasional Provinsi/Badan Narkotika Nasional Kabupaten/Kota, Dinas 
Kesehatan, Dinas Sosial, Kejati/Kejari dan Polda/ Polres untuk tingkat daerah. ${ }^{29}$

Ketua tim assesmen terpadu membuat laporan setiap 1 (satu) bula sekali. Laporan disampaikan kepada Deputi Bidang Rehabilitasi c.q Direktorat Penguatan Lembaga Rehabilitasi Instansi Pemerintah dengan tembusan masing-masing instasi terkait oleh ketua tim assesmen terpadu sebelum tanggal 10 (sepuluh) bulan berikutnya dengan menggunakan formulir pencatatan dan pelaporan menggunakan format yang telah ditetapkan oleh Badan Narkotika Nasional. ${ }^{30}$ Pelaksanaan monitoring pada kasus-kasus yang sudah masuk ke dalam proses peradilan maka jaksa penuntut umum harus memberitahukan hasil persidangan serta putusan hakim kepada ketua tim assesmen terpadu. ${ }^{31}$

Petugas assesmen berhak mendapat perlindungan atas keselamatan dirinya dari institusi yang memerintahkan. Apabila terjadi tindak kekerasan dan/atau tindakan lainnya yang membahayakan petugas assesmen maka petugas assesmen wajib melaporkan diri kepada pihak yang berwajib untuk medapatkan perlindungan sesuai dengan ketentuan perundangundangan. Pada kondisi di mana pecandu dan korban penyalahgunaan narkotika melarikan diri pada saat dilaksanakannya assesmen menjadi tanggung jawab penyidik. ${ }^{32}$

\section{KESIMPULAN}

Berdasarkan hasil penelitian dan pembahasan di atas, maka dapat diambil kesimpulan sebagai berikut:

1. Proses penerapan rehabilitasi bagi pecandu dan korban penyalahgunaan narkotika oleh Balai Rehabilitasi Narkotika Kabupaten Bogor sudah sesuai dengan peraturan perundang-

29 Wawancara dengan Kepala Badan Narkotia Nasional Kabupaten Bogor, Pada Tanggal 7 Maret 2018.

$$
\begin{aligned}
& 30 \text { Ibid. } \\
& 31 \text { Ibid. } \\
& { }^{32} \text { Ibid. }
\end{aligned}
$$

undangan. Namun, tidak menutup kemungkinan kekurangan itu selalu ada dalam menjalankan aturan tersebut.

2. Pelaksanaan assesmen terhadap korban penyalahgunaan narkotika pada Kepolisian Republik Indonesia sama dengan yang dilaksanakan oleh Badan Narkotika Nasional, yaitu jika korban penyalahguna atau pecandu narkotika melakukan pelaporan tanpa proses penangkapan maka pihak Kepolisian akan mengarahkan/merekomendasi langsung ke Institusi Penerima Wajib Lapor (IPWL) dan jika korban penyalahguna atau pecandu narkotika tertangkap oleh pihak Kepolisian maka prosesnya, penerimaan permohonan assesmen dari penyidik paling lama 1x24 (satu kali dua puluh empat) jam.

\section{SARAN}

1. Peran dari berbagai pihak pun terutama orang tua sangat diperlukan untuk mengawasi perkembangan pertumbuhan anggota keluarganya agar tidak terjerumus barang haram tersebut. Karena setiap orang memiliki tanggung jawab untuk menanggulangi meningkatnya korban dari penyalahgunaa dan peredaran gelap narkotika.

2. Hendaknya dalam persoalan assesmen yang dilakukan oleh tim assesmen terpadu memberi porsi yang sama kepada penyidik yang dapat menangani kasus narkotika baik Badan Narkotika Nasional maupun Kepolisian, misalnya ketua tim assesmen terpadu tidak selalu harus berasal dari Badan Narkotika Nasional tetapi juga dapat dari Kepolisian agar kinerja dapat lebih maksimal. 


\section{UCAPAN TERIMA KASIH}

\section{DAFTAR PUSTAKA}

\section{A. Buku:}

Badan Narkotika Nasional, Pencegahan Penyalahgunaan Narkoba Bagi Remaja, Jakarta: Badan Narkotika Nasional, 2011.

, Petunjuk Teknis Pelaksanaan Assesmen Terpadu Bagi Pecandu dan Korban Penyalahgunaan Narkotika Dalam Poses Hukum, Jakarta: Deputi Bidang Rehabilitasi Badan Narkotika Nasional, 2015.

Dani Krinawati \& Niken Subekti Budi Utami, Pelaksanaan Rehabilitasi Bagi Pecandu Narkotika Pada Tahap Penyidikan Pasca Berlakunya Peraturan Bersama 7 (Tujuh) Lembaga Negara Republik Indonesia, Yogyakarta: Hasil Penelitian Fakultas Hukum Universitas Gadjah Mada, 2014.

Edy Karsono, Mengenal Kecanduan Narkoba \& Minuman Keras, Bandung: CV. Yrama Widya, 2004.

Ninik Widiyanti dan Yulius Waskita, Kejahatan dalam Masyarakat dan Pencegahannya, Jakarta: Bina Aksara, 1987.

Saharudin Bangko, Tim Asesmen Terpadu, Makalah, Diselenggarakan Oleh Badan Nasional Narkotika Tanjung Balai, Tanjung Balai, 2015.

Salim, HS., Erlis Septiana Nurbani, Penerapan Teori Hukum pada Penelitian Tesis dan Disertasi, Jakarta: Raja Grafindo Persada, 2013.

Suteki, Masa Depan Hukum Progesif, Yogyakarta: Thafa Media, 2015.

\section{B. Peraturan Perundang-undangan}

Undang-undang Dasar Negara Republik Indonesia Tahun 1945.

Undang-undang Nomor 2 Tahun 2002 tentang Kepolisian Negara Republik Indonesia.

Undang-undang Nomor 35 Tahun 2009 tentang Narkotika.

Undang-Undang Nomor 48 Tahun 2009 tentang Kekuasaan Kehakiman.

Surat Edaran Mahkamah Agung Nomor 04 Tahun 2010 tentang Penempatan Penyalahgunaan, Korban Penyalahgunaan dan Pecandu Narkotika ke Dalam Lembaga Rehabilitas Medis dan Rehabilitas Sosial.

\section{Internet}


"Lakka Zombie dan Indonesia Darurat Narkoba", https://news.detik.com/berita/d3569388/flakka-zombie-dan-indonesia-darurat-narkoba, Diakses tanggal 30 Juni 2018.

"Sejarah Indonesia Singkat Penderitaan", http://sejarahrakyat.blogspot.co.id/2015/09/sejarah-indonesia-singkat-penderitaan.html, Diakses tanggal 5 Juni 2018. 